\title{
What Is the Supply and Demand for Coloured Wood Products? An Empirical Study in Slovakian Practice
}

\author{
Mariana Sedliačiková ${ }^{1, *(\mathbb{D},}$, Mária Moresová ${ }^{1}$, Patrik Aláč ${ }^{1}$ and Denisa Malá $^{2} \mathbb{D}$ \\ 1 Faculty of Wood Sciences and Technology, Technical University, T. G. Masaryka 24, 96001 Zvolen, Slovakia; \\ maria.moresova@tuzvo.sk (M.M.); patrik.alac@tuzvo.sk (P.A.) \\ 2 Faculty of Economics, Matej Bel University, Tajovského 10, 97590 Banská Bystrica, Slovakia; \\ denisa.mala@umb.sk \\ * Correspondence: sedliacikova@tuzvo.sk; Tel.: +421-907354603
}

check for updates

Citation: Sedliačiková, M.; Moresová, M.; Aláč, P.; Malá, D. What Is the Supply and Demand for Coloured Wood Products? An Empirical Study in Slovakian Practice. Forests 2021, 12, 530. https://doi.org/ 10.3390/f12050530

Academic Editors: Mauricio Acuna, Carmen-Mihaela Popescu and Holger Militz

Received: 27 March 2021

Accepted: 23 April 2021

Published: 25 April 2021

Publisher's Note: MDPI stays neutral with regard to jurisdictional claims in published maps and institutional affiliations.

Copyright: (C) 2021 by the authors. Licensee MDPI, Basel, Switzerland. This article is an open access article distributed under the terms and conditions of the Creative Commons Attribution (CC BY) license (https:/ / creativecommons.org/licenses/by/ $4.0 /)$.

\begin{abstract}
The paper deals with the issue of the colour tones of wood and furniture products. The main aim is to identify the supply of the colour tones of wood and furniture products and to map the interest in these wood colour tones at potential customers in Slovakia. By means of two independent surveys of supply and demand for colour tones of wood and furniture products, various shortcomings have been identified. It is necessary to increase the supply of wood and furniture products with the natural colour of the wood and at the same time in colour tones of grey, white and brown. The current demand for thermowood and modified alder wood is significantly higher than the supply of such products in the Slovak market. The results of the study represent an opportunity for Slovak woodworking and furniture enterprises to adjust their range of products according to the needs of potential customers, which will bring them higher turnover and help to overcome the current problems associated with the "COVID crisis".
\end{abstract}

Keywords: modified woods; colour tones of wood products; demand; supply; woodworking and furniture enterprises

\section{Introduction}

Besides its common use for construction and packaging, wood is also an aesthetically highly appreciated material used in many high-end applications such as furniture and interior design. The presence of visible wood surfaces causes an overall positive impression [1,2]. Ref. [3] found that wood is associated with the attributes of well-being, aesthetics and eco-friendliness. Moreover, it is considered a natural material [4] and environmentally friendly [5], aspects that have become more important in recent years. To fully explore the chance to "translate" this high appreciation into added value, manufacturers should know more about the tastes and preferences of potential consumers. Based on this knowledge, their production-technology and product design could be directed more precisely towards the wishes and preferences of the consumers.

Due to the fact that most solid wood is used in construction, the sorting and classification procedures used by the industry primarily aim at technical properties. Technical properties which relate to use in this area are, e.g., strength, elasticity, dimensional stability, etc. In general, this leads to a situation where "clear" types of solid wood receive a higher grade, whereas all kinds of structural deviations (knots, grain orientation and cracks) are regarded as "defects" and consequently receive a lower grade or are even rejected. This also limits the variety in the finished wood products because of the absence of or the minimal appearance of technical defects such as knots or cracks required [6]. Accordingly, this sorting and classification practice does not at all take into account optical surface parameters, which might be decisive in attracting consumers. There are only a few studies that link the individual appearance of surfaces to consumers' preferences. Ref. [7] found that wood surfaces should have a homogeneous visual appearance. Ref. [8] found that 
diverging/mismatching wood features are more important for people's evaluation than the overall look of a wood surface. Other findings indicate people's appreciation of wood and how they describe it using subjective criteria such as, e.g., "warm," "natural" and "harmonious" [9,10].

Woods differ in texture and colour. This difference depends on the species and soil conditions. The natural wood colours offer chart can be a need for those who are interested in using natural wood colour. Common woods are medium density (hardwoods or softwoods) that features a colour range of light brown to reddish or peach hues. Some woods also have different coloured grains. However, it is interesting to know that some woods have exotic colours. The colour of an object such as wood is determined by its chemical makeup and its quantum mechanical interactions with light (photons). Wood mostly is made from the carbon in chains with hydrogen and some other elements such as nitrogen, oxygen and trace minerals. Most woods are brown because they do not absorb photons that appear brown. In general, hardwoods such as maple wood, walnut wood and oakwood all have dark brown colour and softwoods have lighter colours. Natural wood colours can also be based on the degree of saturation as well as transparency, divided into other groups [11-15].

It can be stated that the knowledge about existing consumer preference groups is assumed to be often vague [16]. Today's sorting practices in the wood processing industries, as well as customized requirements, are rarely adjusted to consumer preferences $[5,17]$. Besides consideration of norms and rules, customization is a common process regarding specific product requirements of business customers in contrast to consumer orientation. It has been found that retailers and consumers even describe their preferences differently [18]. Regarding consumer's perception of wood surfaces, it has been found that special wood features in contrast to clear surfaces are considered important aesthetic features in cabinet doors [19]. This might indicate the relevance of the presence or absence of, for instance, knots to determine different preference classes. As found by [20] in France, diverging preferences could be identified where one group preferred clear surfaces and another group preferred slightly knotty surfaces (small knots). A preference study of Malagasy consumers [21] conclude that aesthetic features such as colour and texture and the density of furniture wood species affect consumers' preferences. Ref. [22] suppose that harmonious and homogeneous surfaces are preferred by consumers, which are achieved with a few knots and even knot patterns in visual product surfaces.

Colours and visual dimension of a product are the number one influencing factor in purchase decision for almost $93 \%$ of people. Colours convey different meanings to different people. It all depends on age, gender, and nationality. So, the necessary question could be how people perceive colours and how colours affect sales. People make subconscious judgement about the product within $90 \mathrm{~s}$ of initial viewing and $90 \%$ of this assessment is based on colour alone. Some research shows that $90 \%$ of information transmitted to the brain is visual, and visuals are processed 60,000 times faster in the brain than text. For instance, $85 \%$ of shoppers say that colour is their primary reason for buying a product. In addition, $66 \%$ of people would not buy a product unless it comes in their preferred colour [23].

Ultimately, it can be stated that the first prerequisite to achieving a higher added value on solid wood in the high-end market segment is to learn more about the preferences of end-consumers regarding wood surfaces. Based on this information, these (subjective) judgements can be "translated" into measurable and quantifiable parameters of the desired end product(s) and allow the whole production and transformation process from the log to the final product to be directed accordingly. This study has focused on learning more about people's preferences on wood surfaces, and other wood properties what should be used as necessary input for the enterprises behaviour to meet those customers' demands and preferences. Derived from an individual tree, every solid wood surface (e.g., board surface) has its unique features, and every consumer might have a different appreciation for it. Apparently, a sorting approach that is individualized according to individual wood 
surfaces and individual consumer preferences is not feasible for practical product design and marketing.

When the product is purchased, its material properties have to be examined in various ways, such as by touching and tapping to hear the sound it makes. This "multimodality" method of examination is one aspect of the perception of material properties. In other words, the perception of material properties is not just visual but can involve multiple senses just such as time and space perception.

Previous research on the multimodal perception of material properties has involved the comparison of two modalities or interactions between two modalities, such as vision and touch e.g., [24,25], vision and audition e.g., [26], audition and touch [27] and vision and action e.g., [28]. For example, [29] demonstrated that the relative weights between vision and touch were considerably altered by directing observers to judge different dimensions of the same textured surface. Strong emphasis was placed either on visual cues regarding the special density of raised dot patterns or tactile cues regarding roughness of the same surfaces. Ref. [24] showed that while material categorization performance was less consistent in the haptic condition than the visual one, ratings correlated highly between the two modalities. Ref. [25] investigated how vision and touch contribute to the perception of naturalness in wood by comparing four psychophysical measurement methods. Their results show a high degree of consistency across these measurement methods, and that both vision and touch are highly correlated predictors of visuotactile perception of naturalness.

Wood is perceived as a suitable material, either in terms of aesthetics or colour for the interior and exterior in residential buildings. Due to this, there are still higher demands for the quality and processing of wood, as well as for its mechanical and physical properties. It can be included among the most used natural materials in the interior and exterior. It is also a very important raw material for the national economy in the construction, furniture and woodworking industries, transport and mining industry [30].

Wood is characterized by its flexibility, strength and has also good heat-insulating properties. The colour of the wood is a very important quality feature, thanks to which people decide when choosing it. We can claim that this is one of the decisive selection criteria [31]. It is used either in its natural colour or the surface of the wood can be treated by colour finishing with coating. There are also external factors that affect the colour change of wood, such as humidity, UV radiation, heat, etc. The wood colour can be distinguished not only by the types of wood raw material but also by part of the tree. The difference in colour is visible in the ground floor parts of the trees and in their top parts [32]. The most significant colour change is in the sapwood and heartwood. With the steaming, the wood colour can be tuned into one colour, as well as the colour of rare tropical woods can be achieved, while all parameters of steaming — time, temperature, pressure, etc.-must be observed. Steaming of wood also serves to unify the colour tones, dimensional stability and to wood softening [33].

According to research of [34], wood colour is a significant property and we dare to say that it is the first feature people observe when looking at the wood. At the same time, the colour of the wood can be a decisive factor when buying products. It is important for the success of woodworking and furniture enterprises that they take into account, first and foremost, the diverse and specific requirements of both loyal and regular customers, but especially the potential customers. In order to attract customers, they must pay attention to their good name, quality of manufactured products, of course, well-functioning internal processes, highly set customer service, ability to satisfy even the most demanding customers and solve their requirements as effectively as possible, improving and expanding the offer, continuously monitor the development of trends in the production of wood products and rising demands of customers.

Trends in this area are constantly changing and enterprises need to respond immediately and flexibly to these changes. The competitiveness of enterprises also depends on technological equipment, on the abilities and skills of employees, but also corporate policy. It is essential to follow customer preferences all the time. Enterprises can offer 
naturally coloured wood in their assortment, but it is rarely used. The most common method of wood treatment is the surface treatment, which includes processes such as staining, bleaching and dyeing of wood [35].

Ref. [36] described that there are four requirements that are key to meeting customer demands. First is to have a supply-chain strategy that is tailored to the requirements of each product and market. Second, to have the capacity to meet demand, which is especially critical given by the long lead times required for adjusting one's global manufacturing footprint. Third, it is the formal sales and operations planning process, so that companies can continually adjust production to meet demand and inventory targets. Fourth, and most critical, is possessing flexibility in planning and execution. Supply chains need to be able to change production runs quickly in response to unplanned shifts in the market.

A perennial problem, which management thinker Peter Drucker labelled one of the "great divides" in management more than 40 years ago, is the disconnection between supply and demand. This division is a key reason why companies are so often trapped into selling excess products well below market rates or lose sales because an inventory shortage makes it impossible to fulfil demand. Bringing the supply and demand sides of an enterprise together can represent a significant opportunity for efficiency and value creation. In addition, as remarkable as it might seem in this age of big data and just-in-time delivery, research suggests that the division between supply and demand is as serious a problem today as it was in the Drucker's time [37].

The objective of scientific research is to identify the offer of colour tones of wood and furniture products and to map the interest in these wood colour tones at potential customers in the Slovak Republic.

\section{Materials and Methods}

\subsection{Experimental}

The purpose of the study is the idea to make the supply of Slovak woodworking and furniture enterprises (WFEs) more efficient in the area of colour tones of their products by identifying the current requirements of potential customers in the domestic market.

\subsection{Data Collection}

To collect the data, it was necessary to carry out two independent questionnaire surveys-the Supply Questionnaire and the Demand Questionnaire. Both surveys were conducted at the same time, from May to September 2020. The random and purposive sampling was used for the selection of respondents into the selected sample. The purposive sampling was used for the selection of woodworking and furniture-making enterprises. Respondents were addressed through electronic forms (questionnaires) sent directly to their addresses.

The supply questionnaire was used to ensure the data collection for the identification of the current state of the supply of colour tones of wood and furniture products (WFPs) on the Slovak market. The questionnaire was structured into two basic parts:

- $\quad$ Part A-4 questions: Characteristics of the enterprise (A1-A4)

- Part B-13 questions: Supply of wood and furniture products (B1-B13).

In part $\mathrm{A}$, the basic characteristics about enterprises were determined (industry, registered seat, the scope of business, legal form and size of the enterprise and length of business). Part B was focused on identification of current WFPs supply on the Slovak market. This part included these questions: main factors preferred at the production of WFPs, used wood species, wood treatment methods and reasons for wood colour treatment, production of colour tones of WFPs, the assortment of WFPs, wood treatment techniques, environmental friendliness of production.

Demand questionnaire served to collect data on the interests of potential customers in colour tones of WFPs in the Slovak market. The questionnaire was also in this case divided into two basic parts:

- $\quad$ Part $X-6$ questions: Demographic characteristics of customers (X1-X6) 
- $\quad$ Part Z-13 questions: Demand for WFPs (Z1-Z13).

Part $X$ contained basic questions for identifying the demographic characteristics of customers (gender, age, residence, education, job position and salary). Part $\mathrm{Z}$ contained a total of 13 questions. Their goal was to determine the demand for colour tones of wood and furniture products in Slovakia. Using the questions in this part, the main factors influencing the purchase of WFPs were identified (such as price, quality, type of wood, technological treatment of wood, preferred colour tones, preference for wood grains, the lifetime of wood products, environmental friendliness and willingness to invest in thermowood).

\subsection{Sample Size}

Sample size refers to the number of participants or observations included in a study. The size of the sample is very important for getting accurate, statistically significant results and running your study successfully. If the sample is too small, you may include a disproportionate number of individuals, which are outliers and anomalies. These skew the results and you do not get a fair picture of the whole population. If the sample is too big, the whole study becomes complex, expensive and time consuming to run, and although the results are more accurate, the benefits do not outweigh the costs [38,39].

The basic sample set for the needs of empirical research of the supply consisted of all woodworking and furniture companies that do business in the Slovak Republic. According to the [40] data, in the year 2020, 5194 enterprises operated in the area of wood-processing industry in SR.

According to the methodology for determining the minimum sample size [39], as stated below, it is possible to determine the minimum sample size of the respondents in order to maintain the condition of generalization of the results.

$$
n \geq \frac{z^{2} \times p \times(1-p)}{c^{2}}
$$

where

- $\quad n$-minimum number of respondents;

- $\quad z$-reliability coefficient (at confidence level of $95 \%$ the variable $z=1.96$ );

- $\quad p$-the proportion of the character (for unknown values it is substituted for $p 0.5$ );

- $\quad c$-acceptable margin of error (significance level was set at 5\%).

After substituting the appropriate values into the formula, the minimum sample size for both surveys was calculated (for WFPs and customers):

$$
n \geq \frac{z^{2} \times p \times(1-p)}{c^{2}} \rightarrow n \geq \frac{1.96^{2} \times 0.5 \times(1-0.5)}{0.05^{2}} \rightarrow n \geq 384 .
$$

The calculation shows that the sample set in the survey of supply and in the survey of demand must consist of at least 384 respondents. As 402 WFEs participated in the survey, it is possible to generalize the results to the whole basic set- the survey of the supply meets the condition of the minimum range. Moreover, 570 potential customers participated in the demand survey. Even in this case, according to the established methodology, the results can be generalized to the whole basic set-the survey of the demand for wood colour tones of WFPs meets the condition of the minimum range.

\subsection{Methods of Evaluation of the Research}

In the first stage of the solution, it was necessary to process a literature review from domestic and foreign authors based on the analysis and synthesis of available secondary sources. In the second stage, it was necessary to design two questionnaires to obtain empirical data on the supply of woodworking and furniture enterprises in Slovakia and on the demand for WFPs from customers in the Slovak Republic. In practice, the survey was conducted using the method of questioning in the form of a questionnaire. The obtained results were evaluated by means of a descriptive method, numerically and graphically. 
The following two hypotheses were formulated, which were based on the findings of the theoretical part:

Hypothesis 1 (H1). It is assumed that woodworking and furniture enterprises and customers mostly focus on wood products that have a natural wood colour.

Hypothesis 2 (H2). It is assumed that woodworking and furniture enterprises and customers, when choosing a particular treated colour tone of wood, usually prefer the brown colour, which is closest to the natural tone of wood and symbolizes nature (wood or earth).

The hypotheses were verified using mathematical-statistical methods, specifically the binomial test. The results of the survey were processed and evaluated by statistical software STATISTICA 10 . When testing the hypotheses, the significance level of $5 \%(\alpha=0.05)$ was used. In the third stage, through the mutual confrontation of the results of two independent empirical surveys, it was possible to identify the main shortcomings in the supply of colour tones of wood and furniture products by enterprises operating in the Slovak Republic. By effective adaptation of the product supply, woodworking and furniture enterprises can better respond to demand. This will also help them keep their business in the current COVID crisis. This stage could be realized on the basis of the use of scientific methods such as summarization, comparison, analysis, synthesis and deduction.

\section{Results and Discussion}

In this part of the scientific study, the results from both realized questionnaire surveys are presented. For better visualization, the results of the supply questionnaire and the results of the demand questionnaire are listed separately in individual subchapters.

\subsection{Results of the Empirical Survey of Supply}

There are 402 woodworking and furniture enterprises operating in the territory of the Slovak Republic that participated in the survey on the supply of colour tones of WFPs. The first part of the questionnaire (marked as A) contained basic characteristic questions. The results obtained from this section are presented in Table 1.

Table 1. Characteristics of woodworking and furniture enterprises (WFEs) - answers on the questions of characteristics of the enterprise (A1-A4).

\begin{tabular}{|c|c|c|c|c|}
\hline Questions & \multicolumn{4}{|c|}{ Answers } \\
\hline \multirow{2}{*}{ A1-industry } & \multicolumn{2}{|c|}{ Woodworking enterprise } & \multicolumn{2}{|c|}{ Furniture enterprise } \\
\hline & \multicolumn{2}{|c|}{$39.55 \%$} & \multicolumn{2}{|c|}{$60.45 \%$} \\
\hline \multirow{2}{*}{ A2-legal form } & JSC & LLC & craft & other \\
\hline & $7.96 \%$ & $31.84 \%$ & $44.28 \%$ & $15.92 \%$ \\
\hline \multirow[t]{2}{*}{ A3-size of enterprise } & $\begin{array}{l}\text { Micro enterprise (up to } \\
10 \text { employees) }\end{array}$ & $\begin{array}{c}\text { Small enterprise } \\
\text { (10-49 employees) }\end{array}$ & $\begin{array}{l}\text { Medium enterprise } \\
\text { (50-249 employees) }\end{array}$ & $\begin{array}{l}\text { Large enterprise (250 } \\
\text { and more employees) }\end{array}$ \\
\hline & $76.86 \%$ & $12.94 \%$ & $5.22 \%$ & $4.98 \%$ \\
\hline \multirow{2}{*}{ A4-length of operation } & Less than 1 year & $1-4$ years & $5-14$ years & 15 and more years \\
\hline & $13.68 \%$ & $43.78 \%$ & $21.39 \%$ & $21.15 \%$ \\
\hline
\end{tabular}

The second part of the survey B was focused on identifying the supply of colour tones of wood provided by Slovak WFEs. Question B1 was used to determine which factor is most important for manufacturers when choosing a material. Up to $80.35 \%$ of respondents prefer the quality of material for the production of WFPs and only $19.65 \%$ of WFEs prefer the price of production materials over quality.

Another question (B2) focused on identifying what products WFEs produce and supply to the market. The majority $(70.40 \%)$ of WFEs focus on the production of solid 
wood products, $16.91 \%$ produce products from chipboard and fibreboard and only $12.69 \%$ of respondents produce products covered with wood veneer. As [41] states, wood is used in various industries such as building industry, production of paper and cardboard, furniture industry, etc. Solid wood is an irreplaceable raw material, especially in the production of musical instruments, as it is characterized by excellent acoustic properties. According to [42-45], in the industrial production of furniture, large-area wood-based materials, adhesives, plastics, fittings and fasteners are of major importance. The method of material processing greatly affects the manufacture and quality of furniture, the economic efficiency of production and the price of the final product. The third question B3 examined how many WFEs use classic, domestic wood plants and which favour exotic wood plants. The survey showed that up to $91.79 \%$ of WFEs in Slovakia produce their products from classic wood plants typical for this area (e.g., spruce, oak, beech and others). The lack of ash wood limits its use only for the production of designed luxury furniture with a high price, and it is little available for the regular customer. Only $8.21 \%$ of respondents work with exotic woods. This issue was followed by question B4, where WFEs listed specific types of wood plant with which they work and use them to produce their products (Figure 1). It is important to emphasize that respondents could mark more than one answer at a time. Detailed results are presented in the following figure. The achieved results are also supported by the research of several authors [46-50], who evaluate Slovakia to be independent in terms of wood production. The area of forest land in the Slovak Republic currently represents $41.2 \%$ of the total area of the state. Wood plants such as spruce, oak and beech have the major representation. In general, the wood with holes caused by insects is not suitable for the production of furniture and wood products. Such a material must be avoided from the production process. Wood material inhabited by blue stain fungi cannot be used for furniture production. At the same time, wood material for furniture production should be without visible cracks or similar mechanical damages. If this happens, the price of the product is a sale or clearance.

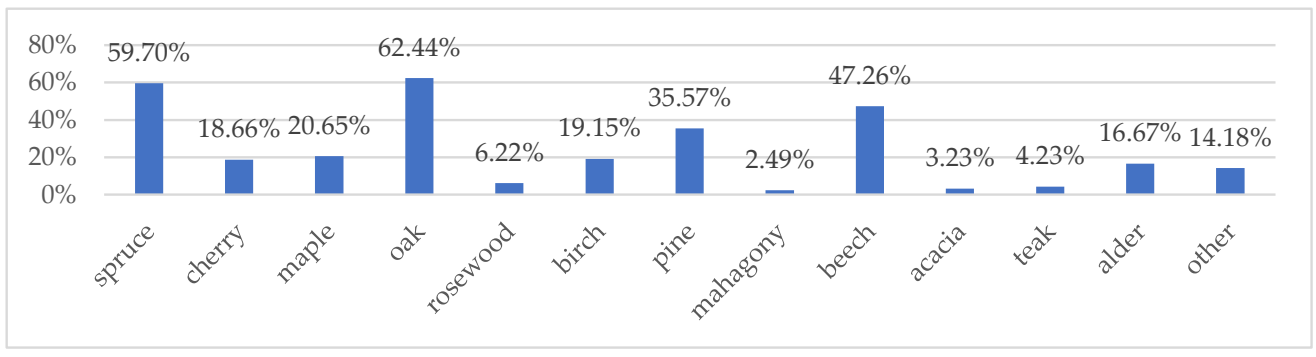

Figure 1. Processed wood plants at the production of woodworking and furniture enterprises (WFPs).

Slovak WFEs prefer at the production predominantly the natural colour of wood $(71.89 \%)$, on the contrary, $28.11 \%$ of producers modify the colour of wood. These results were achieved through the question B5. Hypothesis H1 was also related to this issue, where it was assumed that WFEs mostly focus on wood products that have a natural wood colour. The validity of the hypothesis was verified using the binomial test (Table 2). The results show that the $p$-value is lower than the selected level of significance of $5 \%$, i.e., the hypothesis was confirmed from the point of view of WFEs-WFEs mostly focus on the production of wood products, to which they leave the natural colour of wood.

Table 2. Binomial test results for the hypothesis H1-WFEs.

\begin{tabular}{ccccccc}
\hline \multicolumn{7}{c}{ Binomial Test } \\
\hline & & Category & $\boldsymbol{n}$ & Observed Prop. & Test Prop. & Exact Sig. (2-Tailed) \\
\hline \multirow{2}{*}{ Question } & Group 1 & 1 & 289 & 0.7189 & 0.6 & 0.000 \\
B5 & Group 2 & 0 & 113 & 0.2811 & & \\
& Total & & 402 & 1.0000 & & \\
\hline
\end{tabular}


If it is necessary to treat the wood before the production of WFPs, the objective of the question B6 was to find out which specific wood treatments are used by the WFEs. Figure 2 presents the detailed results. WFEs mostly stated the following treatment: oiling, burning, waxing, stabilization with coloured epoxy resin, brushing and laser engraving. The most common reasons for wood colour modification (question B7) include the need to enhance the wood grain $(57.21 \%$ ) and change of colour tone (51.99\%) or wood impregnation $(43.03 \%)$. Total of $3.23 \%$ of respondents marked the option "other". As [41,42,51] presents, wood as natural and renewable material has a long tradition. The advantages of wood are its aesthetic effect of decorative properties and favourable ecological impact on the environment. Its natural properties predetermine it for the production of furniture and other products for general use. In order for WFEs to preserve the natural properties of wood and its appearance, they use minimal treatments of the purchased wood raw material. If the wood has to be treated, the reason is to improve its aesthetic aspect.

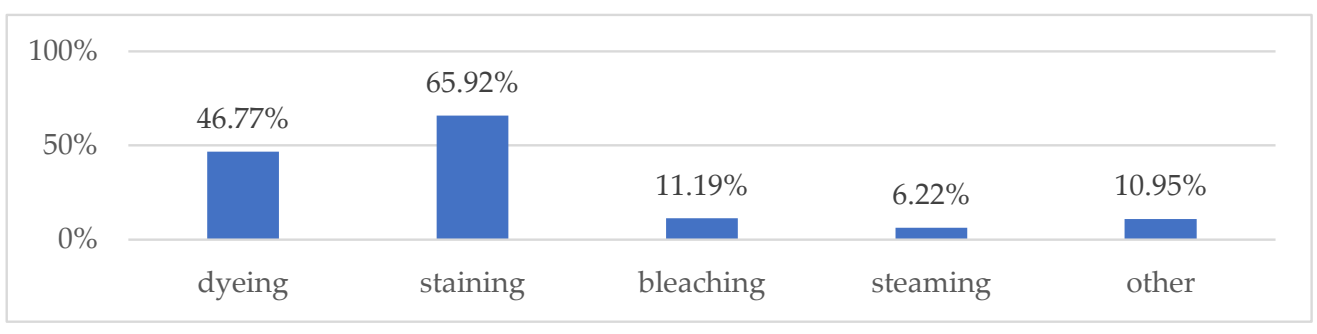

Figure 2. Methods of wood treatment.

The validity of the hypothesis $\mathrm{H} 2$ from the point of view of the WFEs was verified by the question B8: "It is assumed that woodworking and furniture enterprises and customers, when choosing a particular treated colour tone of wood, usually prefer the brown colour, which is closest to the natural tone of wood and symbolizes nature (wood or earth)." The validity of the $\mathrm{H} 2$ hypothesis in terms of WFEs was verified using the binomial test as presented by Table 3 .

Table 3. Binomial test results for the hypothesis H2-WFEs.

\begin{tabular}{ccccccc}
\hline \multicolumn{7}{c}{ Binomial Test } \\
\hline & Category & $\boldsymbol{n}$ & Observed Prop. & Test Prop. & Exact Sig. (2-Tailed) \\
\hline \multirow{4}{*}{ Question } & Group 1 & 0 & 163 & 0.2074 & 0.5 & 0.000 \\
B7 & Group 2 & 0 & 65 & 0.0827 & & \\
& Group 3 & 1 & 318 & 0.4046 & & \\
& Group 5 & 0 & 89 & 0.1132 & & \\
& Group 6 & 0 & 114 & 0.1450 & & \\
\cline { 2 - 7 } & Total & & 37 & 0.0471 & & \\
\hline
\end{tabular}

The results show that the $p$-value (0.000) is lower than the selected level of significance $(\alpha=0.05)$. With regard to the identified state and its verification by a selected statistical test, it is possible to confirm the validity of hypothesis H2, i.e., that WFEs, in case of production of a particular treated colour tone of wood, usually prefer the brown colour, which is closest to the natural tone of wood.

At the production of WFPs, which are supplied on the market, the enterprises prefer mainly matt wood $(75.37 \%)$ to gloss wood $(24.63 \%)$. The gloss of the wood, as [42] presents, depends on the composition of the wood mesh, cut sectioning and also wood-processing quality. In practice, high-density wood has a higher gloss, where the processing cost is higher and subsequently reflected in the final price of the products. This is also one of the reasons why wood without gloss, which has a low density, is used in practice. 
In the next question, the respondents had to state which specific wood products they produce with colour treatment by any technological process (Figure 3 ).

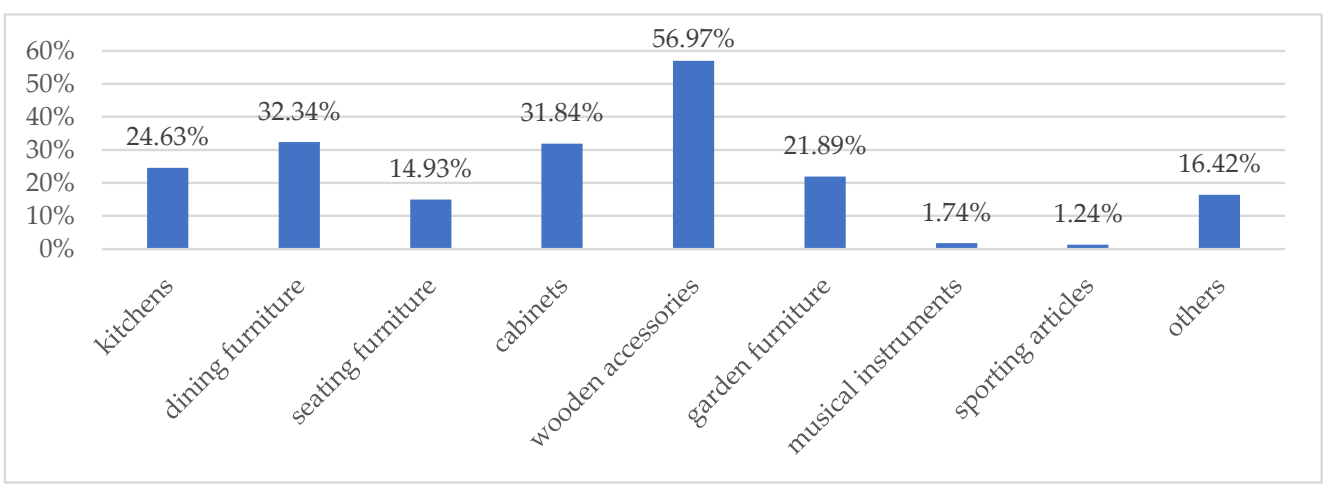

Figure 3. Supply of wood products treated by dyeing.

The innovative way of wood treatment by hydrothermal regulation by steaming or cooking in order to change the colour tone is actually used by $53.48 \%$ of Slovak WFEs, $10.70 \%$ of respondents know this type of wood treatment but do not use it and up to $35.82 \%$ of WFEs have never heard about this method of wood treatment. In case of wood treatment by the process of steaming, according to $[48,50,51]$, it is necessary to observe parameters that influence this process. It is essential to set and maintain the temperature, pressure and vacuum in the steaming equipment. The application of hydrothermal treatment by steaming in WFEs is conditioned by the initial investment in the equipment, which, in practice, many micro-enterprises cannot afford, where we include mainly craftsmen.

Ecologically thermally modified alder wood with saturated water vapour acquires the colour of mahogany wood, and thus, it is a cheaper variant. In the penultimate question, it was found that up to $66.67 \%$ of Slovak WFEs treat alder wood in this way, thus providing customers with a more affordable imitation of mahogany wood. On the other hand, 33.33\% of WFEs prefer to produce their products directly from tropical wood, i.e., mahogany. Enterprises are constantly looking for a competitive advantage in the market. They try to fight against the competition in various ways, such as price, advertising, marketing, a better multi-purpose product or quality [52,53]. Of course, there is competitiveness also in the woodworking and furniture industry.

In terms of the environmental friendliness of ongoing wood colour treatment processes, up to $72.64 \%$ of companies prefer stains and paints on the ecological basis that are environmentally friendly. The remaining $27.36 \%$ of respondents indicated that they do not care whether the materials used for wood colour treatment are environmentally friendly. Ref. [54] draw attention to the fact that many companies have begun to apply the principle of socially responsible business, where, in addition to economic and social factors, the emphasis is also placed on environmental factors.

\subsection{Results of the Empirical Survey of Demand}

A total of 570 respondents actively participated in the survey on customer demand for colour tones of wood and furniture products in Slovakia. Briefly, $52.63 \%$ of women and $47.37 \%$ of men were actively involved in the survey. Moreover, $53.33 \%$ addressees live mainly in the towns, and $46.67 \%$ of respondents live in a rural village. The basic characteristics of the respondents are shown in Table 4. 
Table 4. Answers of respondents on the questions X3-X5.

\begin{tabular}{|c|c|c|c|c|c|}
\hline Questions & & & Answers & & \\
\hline \multirow{2}{*}{$\begin{array}{l}\text { X3-age of } \\
\text { respondent }\end{array}$} & up 25 years & $26-35$ years & $36-45$ years & $46-55$ years & 56 and more \\
\hline & $25.67 \%$ & $34.82 \%$ & $31.12 \%$ & $7.00 \%$ & $1.39 \%$ \\
\hline \multirow{2}{*}{$\mathrm{X} 4$-education } & basic education & $\begin{array}{l}\text { secondary without } \\
\text { graduation }\end{array}$ & $\begin{array}{l}\text { secondary with } \\
\text { graduation }\end{array}$ & $\begin{array}{l}\text { university } \\
\text { education }\end{array}$ & - \\
\hline & $2.11 \%$ & $3.51 \%$ & $46.14 \%$ & $48.24 \%$ & - \\
\hline \multirow{4}{*}{ X5-job position } & student & private sector employee & public sector employee & sole trader & entrepreneur \\
\hline & $20.65 \%$ & $34.44 \%$ & $21.65 \%$ & $19.05 \%$ & $1.93 \%$ \\
\hline & unemployed & pensioner & other & - & - \\
\hline & $1.4 \%$ & $0.88 \%$ & $0 \%$ & - & - \\
\hline
\end{tabular}

Figure 4 presents the monthly income of the respondents. Refs. $[55,56]$ claim that social inequalities significantly influence the quality of life. As [57] emphasizes that the income of the population and the amount of their investment are characteristic features that affect people's lives in society and the quality of their housing and are the basis for creating social inequalities. The status of inclusion in a particular social group is passed from generation to generation, and thus groups of people in a certain social hierarchy are created.

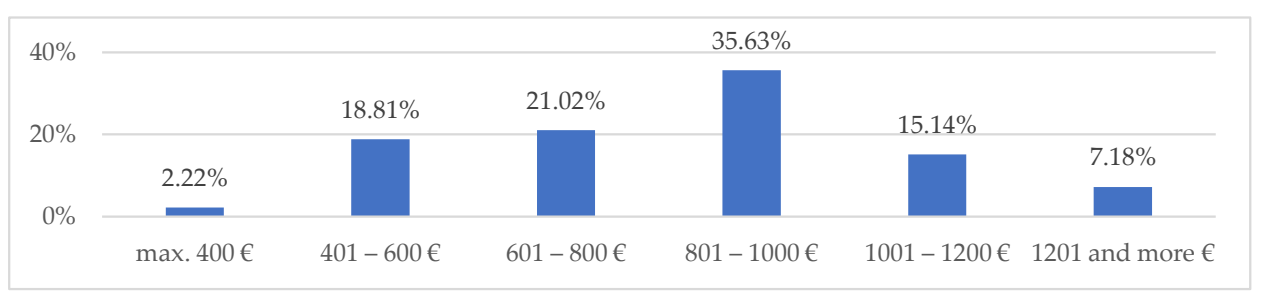

Figure 4. Monthly income of the customers of coloured wood.

In the second part of the questionnaire survey (marked as Z), attention was focused on determining the demand for colour tones of wood among potential customers. The question Z1 examined, which factor plays the biggest role at the purchase of the wood products. The first most important factor is the quality of the products, which is stated by up to $42.28 \%$ of respondents, the second main criterion is the price $(26.67 \%)$, followed by the colour tone of the wood $(19.12 \%)$. Other respondents $(10.35 \%)$ prefer products made from a specific wood plant, and $1.58 \%$ of respondents could not express their opinion. The achieved results correspond with the researches of other authors [58-61], as investments of the customers into the wood products are mainly on the long-term basis. Therefore, they are willing to prefer quality and pay more.

The aim of question Z2 was to find out whether potential customers care about the type of wood. As many as $67.54 \%$ of respondents answered the question positively, on the other hand, $32.46 \%$ said that they do not care about the type of wood. As [5,62-64] state, type of wood plant is very important in most cases, e.g., in musical instruments. Individual types of wood differ in their properties, such as moisture, density, strength, flexibility, plasticity, hardness and resistance and others. Subsequently, the quality of a specific type of product will also depend on the type of wood, while it is necessary to take into account whether the product will be placed in interiors or exteriors.

The next question (Z3) determined which material they prefer in the manufacture of furniture. The results are shown in Figure 5. 


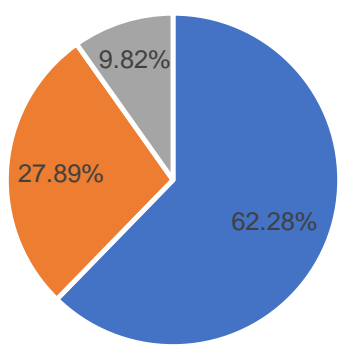

- furniture produced from solid wood

- furniture produced from chipboard and fibreboard

- furniture covered with wood veneer

Figure 5. Preferred material for the production of furniture.

The basic domestic wood plants in Slovakia include spruce, beech and oak and the question $\mathrm{Z4}$ focused on the identification of the preferences of the respondents in terms of domestic and exotic wood plants. The results revealed that $94.39 \%$ of potential customers prefer domestic woods. Only $5.61 \%$ of respondents are interested in tropical woods. Detailed results on the most frequently purchased tree species (question Z5) are presented in the Figure 6. Respondents could indicate more options.

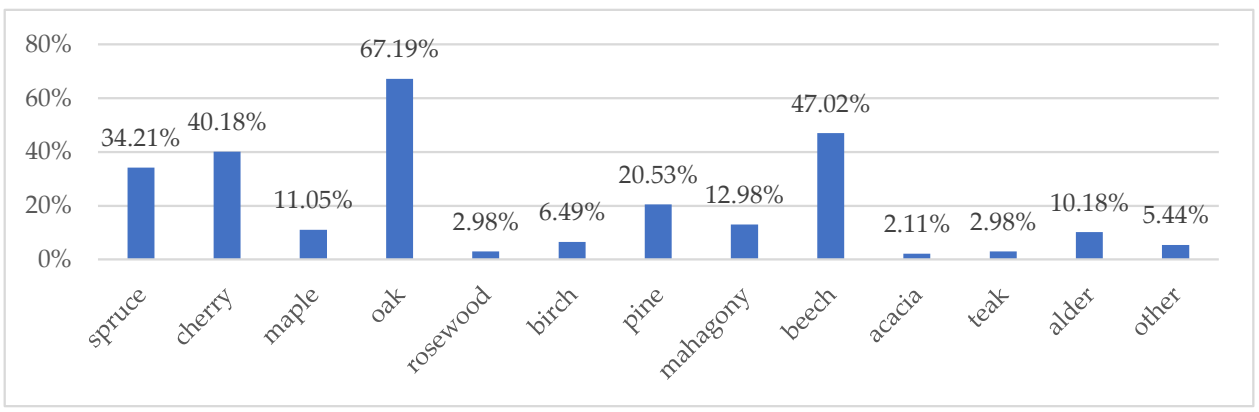

Figure 6. Most frequently purchased types of woods.

The respondents indicated in the question Z6, whether they prefer a natural wood tone or coloured. Up to $80 \%$ of potential customers prefer natural wood tone and only $20 \%$ prefer a colour tone. The results obtained in question Z6 were input data to verify hypothesis $\mathrm{H} 1$ from the customer's point of view. The results of the binomial test (Table 5) confirmed that the majority of customers incline to the purchase of wood and furniture products that have preserved a natural colour of wood. The Hypothesis H1 was confirmed (Table 5).

Table 5. Results of the binomial test to the Hypothesis H1—customers.

\begin{tabular}{ccccccc}
\hline & & \multicolumn{7}{c}{ Binomial Test } \\
\hline & & Category & $\boldsymbol{n}$ & Observed Prop. & Test Prop. & Exact Sig. (2-Tailed) \\
\hline \multirow{2}{*}{ Question } & Group 1 & 1 & 456 & 0.8 & 0.7 & 0.000 \\
Z6 & Group 2 & 0 & 114 & 0.2 & & \\
& Total & & 570 & 1.0 & & \\
\hline
\end{tabular}

One of the most important questions in this part of the survey was certainly the Z7 question, what colour tones the respondents are interested in. The obtained data were used also for the validation of the Hypothesis H2. According to the Table 6, the $p$-value (0.000) is lower than the selected significance level of $5 \%(\alpha=0.05))$. With regard to the identified condition and its verification by performing a binomial test, it is possible to confirm the validity of hypothesis $\mathrm{H} 2$ from the customer's point of view, i.e., most customers, when 
choosing a particular treated colour tone of wood, usually prefer the brown colour, which is closest to the natural tone of wood.

Table 6. Results of the binomial test to the Hypothesis H2-customers.

\begin{tabular}{ccccccc}
\hline & & \multicolumn{7}{c}{ Binomial Test } \\
\hline & Category & $\boldsymbol{n}$ & Observed Prop. & Test Prop. & Exact Sig. (1-Tailed) \\
\hline \multirow{4}{*}{ Question } & Group 1 & 0 & 248 & 0.2232 & 0.5 & 0.000 \\
Z7 & Group 2 & 0 & 75 & 0.0675 & \\
& Group 3 & 1 & 453 & 0.4077 & \\
& Group 4 & 0 & 194 & 0.1746 & \\
& Group 6 & 0 & 134 & 0.1206 & \\
\hline
\end{tabular}

The results of the survey also showed that potential customers prefer matt wood $(67.19 \%)$ to wood with gloss (32.81), as respondents stated in question Z8. At the same time, it was found (question Z9) that wood with an intensive grain (62.81\%) is more interesting for the respondents than treated wood without visible grain (37.19\%). Thermally treated wood "thermowood" is one of the most innovative treatment methods. Thermowood is characterized by increased durability, which predestines it for outdoor exposures. Thermal modification of wood is focused on improving the resistance of wood to water and biological pests [65]. As follows from the question Z10,77.19\% of potential customers are willing to invest in thermowood, on the other hand $22.81 \%$ of respondents are not willing to invest in thermowood. Thermal modification of wood could bring customers better wood quality and its wider utilization, as declared by [65-68].

At present, the public puts a generally strong emphasis on the balance between meeting customer needs and the environmental friendliness of production. For this reason, question Z11 examined the respondents' interest in whether an ecological procedure was used to treat the colour of the wood. The results confirmed that even in the field of wood dyeing, the vast majority of potential customers care about the ecological dyeing of wood, as indicated by $52.63 \%$ of respondents. On the other hand, $47.37 \%$ of respondents are not interested in the environmental friendliness of wood-dyeing procedures, or WFPs. One of the main trends, typical for the 21st century, is a healthy lifestyle and increased interest of individuals and communities in nature. The fact that people now have more information has also contributed to the increase in these perceptions. Environmental awareness can be understood as a combination of value orientations and attitudes towards environmental protection, knowledge of the environment and their corresponding dispositions for action. A customer, oriented in this way, creates needs related to better environment protection-a segment of customers with environmental needs is emerging on the market. If a company wants to satisfy such a segment, it must adapt its product to specific requirements $[69,70]$.

The penultimate question (Z12) focused on the durability of wood products. According to the achieved results, it is the long-term life of wood products that is highly preferred by potential customers (93.68\%). Only $6.32 \%$ of respondents do not care about the lifetime of wood products.

The last question in this questionnaire (Z13) examined what respondents would prefer when buying, whether steamed alder or mahogany wood. The main reason for the investigation was that steamed alder acquires the colour of mahogany wood, thus representing a cheaper variant. In this case, the majority of potential customers $(67.54 \%)$ would choose a cheaper option, i.e., steamed alder. On the contrary, $32.46 \%$ of respondents are willing to pay extra for real mahogany wood. The furniture and the interior equipment represent the nature, preferences, possibilities and personality of the owner of the house. When choosing, it is necessary to take into account which materials will be used, what will be the choice of colours and the final layout of the objects. The aim is to ensure the functionality of the interior, as well as to create an environment full of peace and well- 
being $[58,59,64]$. As the authors $[61,71,72]$ agree, since the ancient time people have had many reasons for utilization of wood. They were attracted not only by the availability of this material but also by its beauty, combined with the practical aspects, durability and feeling of warmth that people perceive when touching it. At the same time, wood evokes at people connection with nature and flow of positive energy.

\subsection{Identified Main Shortcomings of Supply vs. Demand for Colour Tones of Wood}

By summarizing the questionnaire surveys of demand and supply for coloured wood, several shortcomings were identified that WFEs should eliminate in order to meet customer needs more effectively. In the area of production of wood products from solid wood, supply $(70.4 \%)$ perfectly covers demand $(62.28 \%)$, but in the production of furniture from chipboard and fibreboard, the demand is higher than the current supply on the Slovak market (by 10.98\%). As [42] emphasizes, chipboards and fibreboards are mostly used at the production of furniture, which affects the price of final products, but also their manipulability. Solid wood is too heavy, and it is better to use wood-based materials, especially in the production of cabinets.

For most potential customers $(67.54 \%)$, it is important what type of wood is used to produce specific WFPs. According to the requirements, customers are more interested in classic wood plants $(94.39 \%)$ compared to what they can currently find on the market $(91.79 \%)$. The detailed results of demand and supply for specific tree species are compared in Figure 7. According to [41,51], people are connected with nature, and wood has since ever served people as a key material, whether for the production of dwellings (later houses), tools, equipment, etc. People perceive the nature around them. As Slovakia is independent in terms of wood production, the demand for WFPs from domestic woody plants (e.g., spruce, cherry, maple, oak, birch, pine, beech, etc.) is dominant $[50,54,61]$.

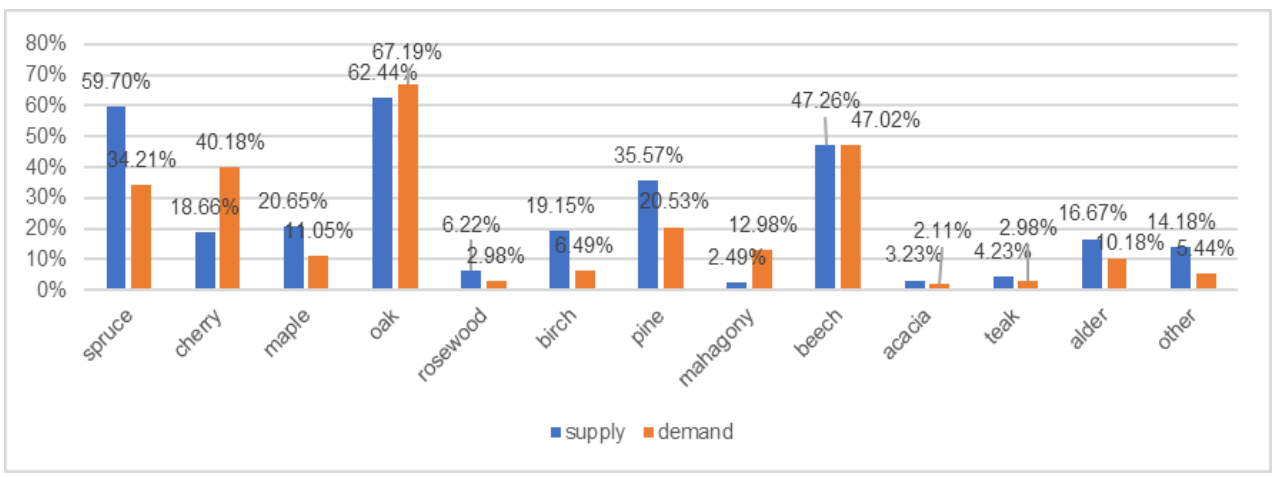

Figure 7. Comparison of demand and supply for specific types of wood plants.

Similarly, it is necessary for WFEs to increase the number of naturally coloured products by $8.11 \%$, while the supply of wood-coloured WFPs may decrease by this percentage. The preference of wood products, which have its natural colour, was also confirmed by the results of the binomial test used to verify the validity of hypothesis H1. By the hypothesis, the authors of the study confirmed that customers mostly focus on wood products that have a natural wood colour, and at the same time, the WFEs mostly produce wood products that have a natural wood colour. In addition, it is essential that supply covers the current demand for glossy wood, which exceeds supply by $8.18 \%$. The survey also revealed preferences of the potential customers in the colour tones of WFPs. After comparing them with the offer on the market, shortcomings were identified, especially in the availability of grey, white and brown tones of WFPs. The detailed results are presented in Figure 8. As the authors $[52,55,56,59,61]$ agree, customer preferences are constantly changing. The main factors that influence the current needs of customers are, in particular, culture (subculture and social class), social factors (reference group, family, roles and statuses), personal factors (age, occupation, economic conditions, lifestyle, personality and self-awareness) and 
psychological factors (motivation, perception, learning, opinions and attitudes). This issue was related also the hypothesis $\mathrm{H} 2$, which confirmed that in case of choosing a particular treated colour tone of wood of WFPs, customers usually prefer the brown colour, which is closest to the natural tone of wood and symbolizes nature. This hypothesis also verified that the WFEs mostly produce WFPs just right in this colour.

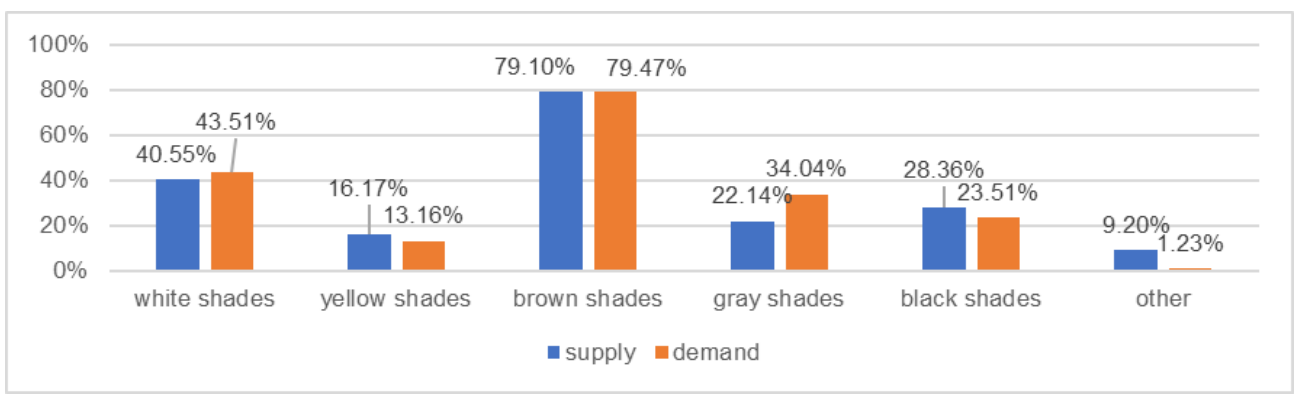

Figure 8. Comparison of supply and demand for specific colour tones of WFPs.

WFEs offer a wide range of wood products on the market such as kitchens, dining and seating furniture, cabinets, wood accessories, garden furniture, musical instruments, sports equipment or other products that have a minority representation. When processing wood, the WFEs operating on the Slovak market use mostly staining, dyeing or bleaching of wood. The producers indicate main reasons for the modification of colour of the wood, which include the intensification of the wood grain, change the colour tone and impregnation. In this case, the needs of potential customers are perfectly covered, who in the first place prefer the enhanced grain of wood $(62.81 \%)$.

As in other sectors, innovations are also emerging in the wood processing industry to make the use of wood more efficient. As [65] claim, thermowood is characterized especially by long durability and application in exteriors. Currently, however, only $53.48 \%$ of WFEs produce thermowood, which according to the findings does not cover the market demand. As many as $77.19 \%$ of potential customers are willing to invest in thermowood. The inclination to invest in thermowood can also be associated with customer demand for long lifetime of wood products (93.68\%). A slight shortage in the supply on the Slovak market of WFPs was also identified for modified alder wood. Steamed alder (as an imitation of an exotic wood-mahogany) is required by $67.54 \%$ of potential customers, while only $66.67 \%$ of WFEs are involved in the production of such products. Alder wood can be replaced by beech or birch wood, but the colour should be changed by appropriate surface finishing or hot steam treatment. As the authors $[58,59,64,73-76]$ agree, it is essential that enterprises invest capital into the improvement of their production and bring customers products that meet their requirements. Otherwise, these enterprises will notice a decline in sales and potential customers will look for what they need from the competition. In the long-term aspect, their business will become unsustainable.

This scientific study identified (through a comprehensive mapping of the supply and demand for colour tones of WFPs offered on the Slovak market) shortcomings, which represent an opportunity for WFEs to improve their assortment they offer to potential customers. Improvement of the supply according to the current needs of customers will bring higher revenues to these enterprises and, at the same time, help them to overcome the current problems associated with the COVID-19 crisis. The text continues here.

\section{Conclusions}

Wood is characterized by its flexibility and strength and has good heat-insulating properties. The colour of wood is a very important quality feature, thanks to which people decide when choosing it. It can be stated that this is one of the decisive criteria in the selection. It is the colour that people notice at the first look at wood, so the colour of 
wood has an undeniable influence on the very decision of a potential customer to buy a particular product.

The market with WFPs can longstanding function only on the basis of balanced supply and demand for these products. However, trends are constantly changing and enterprises need to respond immediately and flexibly to these changes. The competitiveness of Slovak WFEs also depends on technological equipment, on the abilities and skills of employees, but also on corporate policy. It is essential to constantly monitor the customer preferences.

Two independent empirical surveys comprehensively mapped the current supply and demand for colour tones of WFPs on the Slovak market. The study revealed the main shortcomings on the supply side and, conversely, the preferences and needs of potential customers.

The hypothesis H1 verified that the WFEs and customers mostly prefer wood products with natural wood colour. These results have been supported by validation of the hypothesis $\mathrm{H} 2$ that WFEs and customers, in case of selecting a specific treated colour tone of WFPs, prefer most often brown colour, which is closest to the natural tone of wood and symbolizes nature.

The current shortcomings of the supply of WFPs products on the market related to the wood colour tones include the need to increase the number of offered products with natural wood colour, and the supply also faces problems with the lack of grey, white and brown tones in the supplied production of WFPs. The business environment continuously influences the activities in an enterprise and the decisions of their managers. It is essential that to ensure the stability, competitiveness and long-term sustainability of the enterprise, managers should make effective decisions, especially in the field of production and marketing. In the area of production of wood products from solid wood, supply perfectly covers demand, but in the production of furniture from chipboard and fibreboard, the demand is higher than the current supply in the Slovak market. According to the requirements, customers are more interested in classic wood plants (e.g., cherry or oak) compared to what they can currently find in the market. Similarly, it is necessary for WFEs to increase the number of naturally coloured products by $8.11 \%$. In addition, it is essential that supply covers the current demand for glossy wood, which exceeds supply by $8.18 \%$. The survey also revealed preferences of the potential customers in the colour tones of WFPs. After comparing them with the offer on the market, shortcomings were identified, especially in the availability of grey, white and brown tones of WFPs. A slight shortage in the supply on the Slovak market of WFPs was also identified for modified alder wood. It is essential that more WFEs invest in the production of thermowood and also in the modification of alder wood (which imitates the exotic mahogany wood). The main factors that influence the current needs of customers are, in particular, culture (subculture and social class), social factors (reference group, family, roles and statuses), personal factors (age, occupation, economic conditions, lifestyle, personality and self-awareness) and psychological factors (motivation, perception, learning, opinions and attitudes). Improvement of the supply according to the current needs of customers will bring higher revenues to these enterprises.

It can be concluded from these findings that there is currently a room to improve the supply of colour tones of wood on the Slovak market and if the Slovak WFEs fail to do so, there is a room for a new competitor to enter the market, who will use the existing market gap.

Author Contributions: Conceptualization, M.S.; methodology, M.S., M.M., P.A. and D.M.; software, M.S. and M.M.; validation, M.S. and M.M.; formal analysis, M.S., M.M. and P.A.; investigation, M.S.; resources, M.M., P.A. and D.M.; data curation M.S., M.M. and D.M.; writing-original draft preparation, M.S. and M.M.; writing—review and editing, M.S.; M.M., P.A. and D.M.; visualization, M.M. and M.S.; supervision, M.S.; project administration, M.S.; funding acquisition, M.S., D.M. All authors have read and agreed to the published version of the manuscript.

Funding: This research received no external funding.

Data Availability Statement: Not applicable. 
Acknowledgments: The authors are grateful for the support of the Slovak Research and Development Agency, grant number APVV-18-0520, APVV-18-0378, APVV-17-0456, and APVV-17-0583, by funds of KEGA project KEGA 005TU Z-4/2020 and project LignoPro-ITMS: $313011 \mathrm{T720.}$

Conflicts of Interest: The authors declare no conflict of interest.

\section{References}

1. Rice, J.; Kozak, R.; Metner, M.; Cohen, D. Appearance Wood Products and Psychological Well-Being. Wood Fiber Sci. 2006, 38, 644-659.

2. Ridoutt, B.G.; Ball, R.D.; Killerby, S.K. Wood in the Interior Office Environment: Effects on Interpersonal Perception. Forest Prod. J. 2002, 52, 23-30.

3. Gold, S.; Fubik, F. Consumer Attitudes towards Timber as a Construction Material and Toward Timber Frame Houses-Selected Finding of a Representative Survey among the German Population. J. Clean. Prod. 2009, 17, 303-309. [CrossRef]

4. Nyrud, A.Q.; Bringslimark, T. Is Interior Wood Use Psychologically Beneficial? A Review of Psychological Responses toward Wood. Wood Fiber Sci. 2010, 42, 202-218.

5. Pakarinen, T. Success Factors of Wood as a Furniture Material. Forest Prod. J. 1999, 49, 79-85.

6. DIN EN 1611-1:2002-11. Sawn Timber-Appearance Grading of Softwood-Part 1: European Spruces, Firs, Pines, Douglas Fir and Larches; Deutsches Institut für Normung e.V: Berlin, Germany, 2002.

7. Nyrud, A.Q.; Roos, A.; Rødbotten, M. Product Attributes Affecting Consumer Preference for Residential Deck Materials. Can. J. For. Res. 2008, 38, 1385-1396. [CrossRef]

8. Broman, N.O. Visual Impressions of Features in Scots Pine Wood Surfaces: A Qualitative Study. For. Prod. J. 1995, 45, 61-66.

9. Broman, N.O. Attitudes toward Scots Pine Wood Surfaces: A Multivariate Approach. Mokuzai Gakkaishi 1995, 41, $994-1005$.

10. Nordvik, E.; Schütte, S.; Broman, N.O. People's Perceptions of the Visual Appearance of Wood Flooring: A Kansei Engineering Approach. For. Prod. J. 2009, 59, 67-74. [CrossRef]

11. Kuller, R.; Mikellides, B.; Janssens, J. Color, Arousal, and Performance-A Comparison of Three Experiments. Color Res. Appl. 2009, 34, 141-152. [CrossRef]

12. Gejdos, M.; Suchome, J.; Danihelova, Z. Analysis of Qualitative Features Of beech and Oak Trunks Ans a Determinant of the Quality Assessment. Forests 2021, 12, 15. [CrossRef]

13. Ribeiro, N.; Leonel, J.; Rodrigues, M.; Meireles, C.I.; de Almeida Ribeiro, N.M.C. Socioeconomic Aspects of the Forests in Portugal: Recent Evolution and Perspectives of Sustainability of the Resource. Forests 2019, 10, 361.

14. Nicholls, D.L.; Bumgardner, M.S. Challenges and Opportunities for North American Hardwood Manufacturers to Adopt Cus-tomization Strategies in an Era of Increased Competition. Forests 2018, 9, 186. [CrossRef]

15. Bumgardner, M.S.; Nicholls, D.L. Sustainable Practices in Furniture Design: A Literature Study on Customization, Biomimicry, Competitiveness, and Product Communication. Forests 2020, 11, 1277. [CrossRef]

16. Scheer, D.; Hoffmann, E.; Rubik, F. Mit Holz in die Zukunft? Eine Branche am Scheideweg. Available online: https://www.ioew. de/uploads (accessed on 28 July 2020).

17. Weinfurter, S.; Hansen, E.N. Softwood Lumber Quality Requirements: Examining the Suppler/Buyer Perception Gap. Wood Fiber Sci. 1999, 31, 83-94.

18. Bumgardner, M.; Bush, R.; West, C. Knots as an Incongruent Product Feature: A Demonstration of the Potential for CharacterMarked Hardwood Furniture. J. Inst. Wood Sci. 2001, 15, 327-336.

19. Donovan, G.; Nicholls, D. Consumer Preferences and Willingness to Pay for Character-Marked Cabinets from Alaska Birch. Forest Prod. J. 2003, 53, 27-32.

20. Marchal, R.; Mothe, F. Appreciation of Oak Wood (Quercus Robur L, Quercus Petraea Liebl) for the French Consumer and Wood Professionals. Ann. Forest Sci. 1994, 51, 213-231. [CrossRef]

21. Ramananantoandro, T.; Ramanakoto, M.F.; Rajemison, A.H.; Eyma, F. Relationship between Density and Aesthetic Attributes of Wood and Preference of Malagasy Consumers. Ann. For. Sci. 2013, 70, 649-658. [CrossRef]

22. Hoibo, O.; Nyrud, A.Q. Consumer Perception of Wood Surfaces: The Relationship between Stated Preferences and Visual Ho-mogeneity. J. Wood Sci. 2010, 56, 276-283. [CrossRef]

23. Kido, M. Bio-Psychological Effects of Color. J. Int. Soc. Life Inf. Sci. 2000, 18, 254-262.

24. Baumgartner, E.; Wiebel, C.B.; Gegenfurtner, K.R. Visual and Haptic Representations of Material Properties. Multisens. Res. 2013, 26, 429-455. [CrossRef] [PubMed]

25. Overvliet, K.E.; Soto-Faraco, S. I Can't Believe this isn't Wood! An Investigation in the Perception of Naturalness. Acta Psychol. 2011, 136, 95-111. [CrossRef]

26. Fujisaki, W.; Goda, N.; Motoyoshi, I.; Hodehjko, K.; Nishida, S.Y. Audiovisiual Integration in the Human Perception of Materials. J. Vis. 2014, 14, 1-20. [CrossRef] [PubMed]

27. Zampini, M.; Spence, C. The Role of Auditory Cues in Modulating the Perceived Crispness and Staleness of Potato Chips. J. Sens. Stud. 2004, 19, 347-363. [CrossRef]

28. Buckingham, G.; Cant, J.S.; Goodale, M.A. Living in A Material World: How Visual Cues to Material Properties Affect the Way That We Lift Objects and Perceive Their Weight. J. Neurophysiol. 2009, 102, 3111-3118. [CrossRef] 
29. Lederman, S.J.; Thorne, G.; Jones, B. Perception of Texture by Vision and Touch Multidimensionality and Intersensory Integra-tion. J. Exp. Psychol. Hum. Percept. Perform. 1986, 12, 169-180. [CrossRef] [PubMed]

30. Lihra, T.; Buehlmann, U.; Graf, R. Customer Preferences for Customized Household Furniture. J. For. Econ. 2012, 18, 94-112. [CrossRef]

31. Kadleček, F. Ruční Obrábění Dřeva, 1st ed.; Nakladatelství technické literatury: Prague, Czech Republic, 1989.

32. Kubovský, I.; Kačík, F. Zmeny v Hlavných Zložkách Dreva Spôsobené Ožarovaním Povrchu $\mathrm{CO}_{2}$ Laserom, 1st ed.; Technická Univerzita vo Zvolene: Zvolen, Slovakia, 2013.

33. Valenta, V. ThermoWood-Tepelně Upravené Dřevo. Stolár. Mag. Odb. Čas. Pre Podporu Drev. Nábyt. Výrob. 2009, 10, 6-7.

34. Nguyen, T.T.H.; Tran, V.C.; Li, S.; Li, J. Effects of Rosin-Aluminum Sulfate Treatment on the Leachability, Colour Stability, and Decay Resistance of Wood Treated with a Boron-Based Preservative. BioRes 2020, 15, 172-186.

35. Andac, G.T. Consumer Attitudes toward Preference and Use of Wood, Woodenware, and Furniture: A Sample from KAYSERI, Turkey. BioRes 2020, 15, 28-37.

36. Makkonen, M.; Sundqvist-Andberg, H. Customer Value Creation in B2B Relationships: Sawn Timber Value Chain Perspective. J. For. Econ. 2017, 29, 94-106. [CrossRef]

37. Zhang, Y.; Gu, J.; Tan, H.; Di, M.; Zhu, L.; Weng, X. Straw Based Particleboard Bonded with Composite Adhesives. BioRes 2010, 6, 464-476. [CrossRef]

38. Kozel, R. Moderní Marketingový Výzkum: Nové Trendy, Kvantitativní a Kvalitativní Metody a Techniky, Průběh a Organizace, Aplikace v Praxi, Př́nosy a Možnosti; Grada: Prague, Czech Republic, 2006.

39. Kaščáková, A.; Nedelová, G. Dotazníkový Prieskum II.-Overovanie Hypotéz. In Forum Statisticum Slovacum: Vedecký Recenzovaný Časopis Slovenskej Štatistickej a Demografickej Spoločnosti; Slovenská štatistická a demografická spoločnost': Bratislava, Slovakia, 2014; Volume 10, pp. 109-114.

40. FinStat. Databáza Firiem. Available online: https:/ /www.finstat.sk/ (accessed on 28 July 2020).

41. Colkitt, C. Brick Homes vs. Wood Homes. MassReality 2015, 12, 25-36.

42. Joščák, P.O. Možnostiach Dreva a Nábytku z Aspektu Utvárania Životného Prostredia. In Trvalo Udržatel’ný Život; Zborník Zo sympózia: Zvolen, Slovakia, 2000; pp. 127-132.

43. Dzurenda, L. Colouring of Beech Wood during Thermal Treatment using Saturated Water Steams. Acta Fac. Xylologiae Zvolen 2014, 56, 13-22.

44. Dzurenda, L. Hues of Acer Platanoides, L. Resulting from Processes of Thermal Treatment with Saturated Steam. Drewno 2018, 61, 165-176. [CrossRef]

45. Dzurenda, L.; Geffert, A.; Geffertova, J.; Dudiak, M. Evaluation of the Process Thermal Treatment of Maple Wood Saturated Water Steam in Terms of Change of $\mathrm{pH}$ and Color of Wood. BioResources 2020, 15, 2550-2559.

46. Kočner, M.; Šabíková, I.; Čiernik, A. The Importance of the Green Economy in the Context of Green Growth. Econ. Agric. 2015, 15, 89-102.

47. Regec, J. Význam Drevospracujúceho Priemyslu pre Národné Hospodárstvo. Drev. Mag. 2017, 18, 3-5.

48. Potkány, M.; Hitka, M.; Lorincová, S.; Krajčírová, L.; Štarchoň, P. Use of Variators in Applying the Cost Calculation Methodology in Small and Medium Furniture Enterprises Based on Changes in Human Body Dimensions. Drv. Ind. 2019, 70, 29-35. [CrossRef]

49. Lorincová, S.; Stachová, K.; Stacho, Z.; Joniaková, Z.; Blštáková, J.; Lipoldová, M.; Hitka, M. Defining the Differences in Corporate Culture in Wood-Processing and Forest Enterprises. BioRes 2020, 15, 3320-3343. [CrossRef]

50. Langová, N.; Réh, R.; Igaz, R.; Krišták, L'; Hitka, M.; Joščák, P. Construction of Wood-Based Lamella for Increased Load on Seating Furniture. Forests 2019, 10, 525. [CrossRef]

51. Štefka, V. Wood and Formaldehyde in the Living Environment. Život. Prostr 2004, 38, 201-204.

52. Hudáková, I. Theoretical Aspects of Competitive Advantage and Competition. In Proceedings of the 9th International Conference, Munich, Germany, 4-8 September 2011; pp. 1-9.

53. Trzewik, A.; Orlikowski, L.B.; Oszako, T.; Nowakowska, J.A.; Orlikowska, T. The Characterization of Phytophthora Isolates Obtained from Diseased Alnus Glutinosa in Poland. Balt. For. 2015, 21, 44-50.

54. Zhao, Z.-Y.; Zhao, X.-J.; Davidson, K.; Zuo, J. A Corporate Social Responsibility Indicator System for Construction Enterprises. J. Clean. Prod. 2012, 29-30, 277-289. [CrossRef]

55. Axelsson, L.H.; Andersson, I.; Edén, L.; Ejlertsson, G. Inequalities of Quality of Life in Unemployed Young Adults: A Popula-tionBased Questionnaire Study. Int. J. Equity Health 2007, 6, 1-9. [CrossRef] [PubMed]

56. Becker, G.; Philipson, S.T.J.; Soares, R.R. The Quantity and Quality of Life and the Evolution of World Inequality. Am. Econ. Rev. 2005, 95, 277-291. [CrossRef] [PubMed]

57. De Lotto, R. Assessment of Development and Regeneration Urban Projects: Cultural and Operational Implications in Metropolization Context. Int. J. Energy Environ. 2008, 2, 24-35.

58. Ruddell, S.; James, S. The Adoption of ISO 9000, ISO 14001, and the Demand for Certified Wood Products in the Business and Institutional Furniture Industry. Forest Prod. J. 1998, 48, 19-26.

59. Veisten, K. Potential Demand for Certified Wood Products in the United Kingdom and Norway. Forest Sci. 2002, 48, 767-778.

60. Halaj, D.; Sedliacikova, M.; Malá, D. Customer Behavior on the Slovakia Roundwood Market: A Case Study. BioResources 2018, $13,6003-6020$. 
61. Kaputa, V.; Pirc Barčić, A.; Mat'ová, H.; Motik, D. Consumer Preferences for Wooden Furniture in Croatia and Slovakia. BioRes 2018, 13, 6280-6299.

62. Jelacic, D.; Satanova, A.; Sedliacikova, M.; Závadský, J.; Závadská, Z. Process Model of Quality Cost Monitoring for Small and Medium Wood-Processing Enterprises. Drv. Ind. 2015, 66, 329-338. [CrossRef]

63. Sedliacikova, M.; Stroková, Z.; Klementová, J.; Satanová, A.; Moresová, M. Impacts of Behavioral Aspects on Financial DecisionMaking of Owners of Woodworking and Furniture Manufacturing and Trading Enterprises. Acta Fac. Xylologiae Zvolen 2020, 62, 165-176.

64. Potkány, M. The Methodology of Creation of Basic Budgets Types in Commercial Enterprise at the Furniture Sales. Acta Fac. Xylologiae 2009, 51, 105-119.

65. Petrovski, A.; Petrovska-Hristovska, L.; Ivanović-Šekularac, J.; Šekularac, D. Assessment of the Sustainability of Façade Refurbishment. Therm. Sci. 2020, 24, 991-1006. [CrossRef]

66. Dzurenda, L. Colour Modification of Robinia Ppseudoacacia, L. during the Processes of Heat Treatment with Saturated Water Steam. Acta Fac. Xylologiae Zvolen 2018, 60, 61-70. [CrossRef]

67. Dzurenda, L.; Dudiak, M. The Effect of the Temperature of Saturated Water Steam on the Colour Change of Wood Acer Pseudo-Platanus L. Acta Fac. Xylologiae Zvolen 2020, 62, 19-28.

68. Luhas, J.; Mikkilä, M.; Uusitalo, V.; Linnanen, L. Product Diversification in Sustainability Transition: The Forest-Based Bioeconomy in Finland. Sustainability 2019, 11, 3293. [CrossRef]

69. Malá, D.; Sedliačiková, M.; Kaščáková, A.; Benčíková, D.; Vavrová, K.; Bikár, M. Green Logistics in Slovak Small and Medium Wood-Processing Enterprises. BioResources 2017, 12, 5155-5173. [CrossRef]

70. Ottoman, J.A.; Stafford, E.E.; Hartman, C.L. Green Marketing Myopia. J. Environ. Sci. Policy Sustain. Dev. 2006, 48 , 22-36.

71. Neykov, N.; Dobrichov, I.; Antov, P.; Kitchoukov, E.; Halaisan, A.F. Optimality Guidelines for Decision Making in Forest Consolidation in BULGARIA. In Proceedings of the 13th International Scientific Conference WoodEMA 2020 and 31 st International Scientific Conference ICWST 2020, Vinkovci, Croatia, 28-30 September 2020; pp. 289-294.

72. Neykov, N.; Antov, P.; Dobrichov, I.; Halalisan, A.; Kitchoukov, E. The Consolidation of Forest Territories as a Tool to Improve their Management. In Proceedings of the CBU in Economics and Business, Prague, Czech Republic, 18-20 March 2020; Volume 1, pp. 120-125.

73. Gil, W.; Kowalski, T.; Kraj, W.; Zachara, T.; Łukaszewicz, J.; Paluch, R.; Nowakowska, J.A.; Oszako, T. Ash Dieback in PolandHistory of the Phenomenon and Possibilities of its Limitation. Die-Back of European Ash (Fraximus Spp.). In Consequences and Guidelines for Sustainable Management; Swedish University of Agricultural Sciences: Uppsala, Sweden, 2017; pp. 176-184.

74. Hitka, M.; Joscak, P.; Langova, N.; Kristak, L. Blašková, S. Loading-Carrying Capacity and the Size of Chair Joints Determined for Users with a Higher Body Weight. BioResources 2018, 13, 6428-6443.

75. Neykov, N.; Antov, P.; Savov, V. Circular Economy Opportunities for Economic Efficiency Improvement in Wood-Based Panel Industry. In Proceedings of the 11th International Scientific Conference "Business and Management 2020", Vilnius, Lithuania, 7-8 May 2020; Vilnius Gediminas Technical University: Vilnius, Lithuania, 2020; pp. 8-17.

76. Malá, D.; Benčiková, D.; Drugdová, J. Customer Perception of the Green Product. In Zborník Vedeckých Prác z Projektu VEGA 1/0802/16: Vplyv Inovatívnych Marketingových Koncepcii na Správanie Vybraných Trhových Subjektov na SLOVENSKU II.; Belianum: Banska Bystrica, Slovakia, 2018; pp. 162-175. 